\title{
Disabling Images AND The DANgers of Public Perception: A Commentary on The Media's "Coverage" of the Latimer CASE
}

Heidi L. Janz

Recent high-profile murder trials, such as that of O.J. Simpson, have demonstrated beyond doubt the enormous role of the me dia in shaping public perceptions of the facts surrounding a case. Conseque ntly, the public perception of whether or not justice was served in these cases was influenced largely by the media's presentation of the facts. Like the trials of O.J. Simpson, the trials of Saskatchewan farmer Robert Latimer have attracted a great deal of media attention. In 1994, Robert Latimer was tried and convicted of second-degree murder in the death of his daughter Tracy, who was disabled by a severe form of cerebral palsy. As a result of this conviction, Latimer was sentenced to the mandatary minimum of ten years in prison without parole. Latimer appealed this conviction and, in November of 1997, was convicted a second time of second-degree murder. However, the judge in this trial accepted the jury's recommendation that the mandatary minimum sentence be disregarded; he sentenced Latimer to one year in prison and one year under house-arrest. The Crown has decided to appeal this sentence.

There is no question that the media had a tremendous impact on the way that this case was viewed by the public. In fact, in his decision to grant Latimer's first appeal, Chief Justice Bayda refers to "[t]he hundreds of letters received by the appellant and his family, the many petitions and telephone calls, as well as the editorial commentary in the country's newspapers, [which] were an unsolicited, spontaneous (and in many respects an unprecedented) public outcry in response to the sentence." "Because the impact of the media on the public's perception of this case and, inevitably, on the case itself has been so direct and so profound, it behooves us to critically examine the mass media representations of the persons and issues involved in this case.
Throughout both of Latimer's trials, the media has focussed on the human dram a centred around this salt-ofthe-earth farmer and devoted family man who was being prosecuted (or perhaps even persecuted) for acting to end his young daughter's suffering. Tracy, in contrast, was consistently portrayed by the media as what I refer to as a "Cross-Crip." I use the term "Cross-Crip" to describe a person with a severe disability whose life is only an archetypal cross of suffering for herself and others. As such a "Cross-Crip," Tracy Latimer was depicted as one whose pain-filled and burdensome existence was bravely sustained by her stoic and heroic parents. Indeed, most media stories about the Latimer case were constructed around the dichotomy of Tracy as "Cross-Crip" versus Robert as long-suffering, devoted parent. W ithin this dichotomy, it was usually the image of Tracy as "CrossCrip" that the media initially used to capture the public's attention. The description given by Rae Corelli and Frann Harris, two writers for Maclean's, is typical of the mass media's representation of Tracy. They write: ${ }^{2}$

In her short and tormented 12-year life, Tracy Latimer never learned how to walk or talk or even feed herself. Her brain was so severely damaged by congenital cerebral palsy that she had no muscular control and could not sit without help. Because she was incontinent, she always wore diapers.

As someone who is herself severely disabled by cerebral palsy, what disturbed me most about stories like this was the wording. Invariably, Tracy's name w as virtually lost in a barrage of terms describing how 'severely disabled' she was. According to the media, Robert Latimerwas not accused of killing his daughter, he was accused of killing his severely disabled daughter, as if Tracy's dis ability

\footnotetext{
R. v. Latimer, [1995] S.J. No. 402, para. 155.
}

R. Corelli, "M ercy on trial: a child's death revives the euthan asia debate" Maclean 's (21 November 1994) 48-49 at 48 . 
was automatically a mitigating circumstance in her being killed. Furthermore, I cannot help but register the disturbing fact that the media's pat description of Tracy Latimer as someone who 'could not walk, talk, or feed herself,' could apply to many of the friends that I grew up with at the so-called "special" school that I attended from Grades One through Twelve. What's more, according to some of $\mathrm{m} y$ relatives an family acquaintances, it could even apply to me. The majority of the general public, of course, would have no basis for making this type of connection. I would contend, therefore, that the ultimate effect of this type of headline gloss is to establish Tracy as an objectified "Cross-C rip," and there by to lay a foundation for the construction of Robert Latimer as a devoted, self-sacrificing father.

The cover story of the November 28, 1994 issue of Maclean's magazine provides a succinct and accurate model of the way in which Tracy Latimer becomes a socially-constructed "Cross-Crip." In this article, Trina Woodrow, a 22-year-old neighbour who, for several years, had joined the Latimer household for spring seeding each year and stayed until the end of the fall harvest, tells of her experiences with the family. She describes the Latimer household as having "a good atmosphere." ${ }^{3}$ She says of Robert Latimer, "I saw him grouchy, but I don't think I ever heard him or his wife complain about anything." 4 Woodrow's memories of Tracy Latimer, however, are not as positive. She recalls, "I would co me into the house ... or the o ther kids would come in after school and say, 'Hi, Tracy,' and she would smile. But you didn't know whether she was smiling at the roof or the walls. She never did laugh." 5 It is evident that Tracy Latimer, as viewed by her parents' neighbours, ordinary members of the community, was a being totally without the basic hum an capac ity to commu nicate with others. Although she could smile, her inability to commu nicate in ways that couldbe interpreted as "meaningful" by those ordinary members of the community caused her to exist in total isolation from the community. Therefore, she becomes an objectified Other. According to the experiences and perceptions of those ordinary members of the community, she is indeed an alien. Her parents, on the other hand, come to be seen as all the more human in their struggle to carry the burden of caring for a severely disabled child. Their stoicism in bearing, without complaint, their lot in life - namely, having to care for a severely disabled child - is unques- tioningly commended as virtuous. The possibility that this very stoicism may well have been indicative of an emotional and psycholo gical isolation th at ultimately led to Robert Latimer's dec ision to take h is daughter's life is not considered.

Another interesting aspect of the portrayal of Tracy Latimer as a "Cross-Crip" in this article is the emphasis that is placed on the apparently inordinate a mount of care and attention that she required from her parents, and, consequently, the selfless and heroic efforts that her parents made in caring forher and sustaining her life for thirteen years. Trina vividly recalls what an arduous task the Latimers had in feeding their daughter: "She couldn't swallow ... and she puked, oh my God, just about every feeding. She just cough ed and splattered everyw here. It was try a little more and, if that went down, good. They'd try a little more and back up it would come." 6 Trina's mother, Audrey Woodrow, declares in awe, "I've never seen anybody, a nurse or anyone, do things like they did for her." 7 Clearly ass ociated with this emphasis on the Latimers' self-sacrifice in caring for a disabled child is the distressing notion that the other children in the family also become involuntary sacrifices to the overwhelming needs of their disabled sibling. As Trina Woodrow remarks, "When the newborn came into the picture, they hardly had time to look at him. It was all Tracy, Tracy, Tracy." At this point, I would like to make it clear that in no way do I wish to minimize the enormous challenges involved in caring for a child who has a severe disability. However, I think it is important to think about the kind of attitudes and assumptions that motivate the repeated emphasis on the disabled child's incessant need of care, and the constant pressure it puts on the family. We need to ask ourselves to what extent this recurring portrayal of the disabled child as a burden on her/his family contributes to the general tend ency in society to objectify the disabled child, and, in doing so, to isolate that child's family.

As much as Tracy Latimer has become a stereotype constructed by the media, so too has her father. In the case of Robert Latimer however, the stere otype is primarily a positive one. Most commonly, Robert Latimer has been cast by the media alternately as a wellrespected, well-liked member of the community, and as a self-sacrificing parent who had been dealt an extraordinarily difficult lot in life. The following excerpt
D. Jenish and T. Fennell, "What Would You Do: In Saskatchewan, a wrenching verdict of murder reignites a long-simmering debate about mercy killing" Maclean 's (28 November 1994) 16-19.

Ibid. at 18 .

Ibid.
Ibid.

Ibid. 
taken from the January 16, 1995 issue of Maclean's exemplifies this kind of positive stereotyping: ${ }^{8}$

The hundreds of letters overflowing three cardboard boxes in his living room give Rob ert Latimer hope. Last November, Latimer ... was sentenced to a minimum of 10 years in jail after being convicted of second-degree murder for killing his severely disabled 12-ye ar-old daughter, Tracy. Since then, Latimer, 41, has been free on bail, and restricted to his farm by a court order until his appeal is heard ... He spends his days caring for his children, repairing farm equipment and reading the constant flow of letters sent by Canadians who believe that his sentence was too harsh ... $[\mathrm{P}]$ etitions asking the federal cabinet to exercise its rarely used authority to pardon Latimer are also beginning to circulate. "It is helping us a lot," Latimer told Maclean's last week. "W e're very grateful."

Latimer has never denied killing his daughter, who suffered both mentally and physically from cerebral palsy ... Latim er told police at the time of his arrest, he had finally end ed his daughter's suffering ... So far, supporters have donated more than $\$ 60,000$ to cover his legal bills... Ottawa real estate law yer Paul Dioguardi has circulated a clemency petition signed by almost 2,000 Ontario and Quebec residents ... "The severity of the sentence struck me," says Dioguardi. "The justice system has gone off the rails."

Like so many of the media stories about the Latimer case, this article begins with a very strong emphasis on the notion of Robert Latimer as almost a kind of folk hero who has inspired an incredible groundswell of grassroots support from 'ordinary Canadians.' The dominant image is that of a hard-working, well-liked member of the community who has become the victim of an uncompassionate justice system. As such, he spends his days "caring for his children, repairing farm equipment and reading the cons tant flow of letters sent by Canadians who believe that his sentence was too harsh." While I must acknowledge the fact that some dissenting voices from people on 'the other side' of the issue are heard later in the article, it is this initial image of Robert Latimer as victim/folk-hero that remains dominant. The article concludes: "And as he prepare d to

T. Fenne 11, "The M ercy-Killing D ebate: Robe rt Latimer's murder appeal sparks a protest by handicap groups" Maclean's (16 January 1995) 16. sort through an other box of mail last week, Latimer said he was con fident that he will win his appeal. Thousands of Canadians, it seems, are pulling for him." ${ }^{9}$ I find it a rather telling aspect of the repeatedly emphasized image of Robert Latimer as victim/folk-hero that Tracy is virtually obliterated from the reader's or viewer's consciousness. This erasure takes place as the media supplants Tracy, the real victim of a crime, with her father, who is presented as the victim of circumstance.

We may well ask why it is that this eradication of Tracy Latimer as a victim of crime in most media stories about her murder seems to pass as acceptable for the majority of Canadians. It would seem that the main reason for this is the constantly repeated imaging of Robert Latimer as both a caring and compassionate father and a well-liked member of the community. The subheading of an article in the March 1995 issue of Saturday Night reads: "With his little girl in constant pain, Bob Latimer just couldn't see the point of any more operations. Enough was eno ugh." ${ }^{10}$ Another article in the November 28, 1994 issue of Maclean's opens with the following description of R obert Latimer: ${ }^{11}$

Among his friends and neighbors in Wilkie, Sask., 41-year-old Robert Latimer was considered a typical Prairie farmer. Hardworking, clean-living and self-reliant, he w ould repair his vehicles or replace the barn roof himself rather than hire someone. At the local grain elevators, where he sold the wheat grown on his 1,000-acre farm $170 \mathrm{~km}$ west of Saskatoon, he was known as "Laddie" and viewed more as a friend than a customer.

Latimer is thus consistently portrayed as an ordinary person faced with extraordinary hardship. A good deal of emphas is is placed on his traditional values of hard work, clean-living, and, above all, self-reliance. Such a portrayal carries with it the clear implication that the act of murdering his daughter was actually just a misguided expression of these kind of traditional, basic values. The implicit - or sometim es virtually explicit — suggestion is that, because - in his own mind - Robert Latimer was acting out of compassion when he killed his daughter, he should not be treated as harshly as someone who murders out of malice. He is not, after all, a typical murderer.

Ibid.

10 B. Hutchinson, "Latimer's Choice” Saturday Night (March 1995) 39.

11 Jenish and F enne 1l, supra note 3 at 16. 
So, if the mass media is suggesting that what makes the Latimer story such a compelling human drama is that Robert Latimer is not a typical murderer, we need to ask what it is, specifically, that makes Latimer's murder of his daughter Tracy atypical. The obvious answer is, of course, that Robert did not murder Tracy out of malice but rather out of compassion - that his sole motive for suffocating his daughter to death with carbon-monoxide fumes was to stop her pain. However, if we accept this answer, we must then ask the que stion implicated in this answer, namely, would there have been such a great outpouring of public sympathy for Robert Latimer if he had killed an able-bo died child who w as in pain? This is a very pertine nt question since one of the key issues of contention throughout Latimer's trials was the differentiation between Tracy's pain and her disability. In handing down his decision to give Latimer the unprecedented sentence of a year in prison and a year under house-arrest for second-degreemurder, Justice Ted Noble en gages this iss ue, stating that: ${ }^{12}$

Strictly speaking it is only an appeal court's pronouncements on rules of law which are binding on a lower court. The conclusion of the majority of our Court of Appeal was arrived at after it drew certain inferences of fact from the evidence in the first trial. I am not bound by their factual findings and indeed I do not necessarily agree with some of the inferences they drew when I weigh them against the evidence presented to the jury in this trial. One example is the inference the Court drew that Mr. Latimer would never have considered taking Tracy's life had she not been handicapped and in extreme pain. This sugg ests that his decision was at least in part prompted by Tracy's tragic physical debilitation by virtue of her cerebral palsy. That may have been a fair inference for the Court of Appeal to draw from the evidence they were considering but I am bound to say that on the basis of the evidence presented at this trial there is no suggestion, by any witness who testified or for that matter by Crown counsel that he was motivated in any way by her disability. All of the evid ence poin ts to his concern for the pain which he saw flowing from her illness. So on the evidence I heard I could not conclude Mr. Latimer ever considered killing his daughter because she was disabled. In addition the history of his 12 -year relationship with her completely negates such a conclusion.

It is clear from this paragraph that Justice Noble wishes to draw a distinction between Tracy's pain and her disability - a distinction which, by the way, has hardly even been attempted or alluded to in the mainstream media. However, many people working in the area of disability rights have found this kind of distinction to be, at best, problematic. For example, Dick Sobsey, Director of the University of Alberta Developmental Disabilities Centre, writes in a message which appears on the Internet: ${ }^{13}$

Although it has been argued that Mr. Latimer acted to spare his daughter from further suffering, and that he should receive a lighter sentence because of his hum ane intent, he never took the stand in the first trial, so that the notion of "compassionate murder" is based only on hearsay and assumption. While it is important to clearly recognize such acts as unacceptable, even if such intent were clearly demonstrated, the belief that the courts should act on an ASSUMPTION of humane intent is an important issue for people with disabilities and other advocate s for crime vic tims. The so-called evidence that $\mathrm{Mr}$. Latimer was acting in his daughter's interests consists primarily of evidence of the severe nature of her disability. For this to be accepted would imply that EVEN WITHOUT ANY DIRECT EVIDENCE OF INTENT, the mere existence of a severe disability would be enough to excuse the killing of an individual, even when that individual (as in the case of Tracy La timer) had no part in the decision that she should die.
12 R. v. Latimer, [1997] S.J. No. 701, Ruling On Defence Motion Noble J. December 1, 1997 as it appears at http://ww w.radio .cbc.ca/ne ws/latime r.html.
Sobsey, Feb. 7, 1997. GENTECH Archive 8.96-97. Availab le at http $/ /$ www.free.de/gentec/97/msg00121.html 
Like Dr. Sobsey, I am very concerned by the notion that the courts should act on the assumption of human e intent, especially when, as in the Latime $\mathrm{r}$ case, all the evidence of Mr. Latimer's humane intent centres around his distress over the pain Tracy suffered as a result of the severity of her disability. For all his efforts to distinguish Tracy Latimer's pain from her disability in assessing her father's motivation for taking her life, I find that Justice Noble himself appears to associate "Tracy's tragic physical debilitation" with "the pain which [Robert Latimer] saw flowing from her illness." One could, in fact, argue that the pain that Tracy experienced was indeed an inextricable part of the severity of her disability. Thus, the question arises ag ain: would there be such a great outpouring of public sym pathy for Robert Latimer if he had killed an able-bodied child who was in pain? This question was addressed by Dr. Margaret Somerville, of the Centre of Medicine, Ethics, and Law at McGill University, in an interview with the CBC's National Magazine, "Just think how Canada would have reacted if this little girl hadn't been handicapped, and Robert Latimer had killed his twelve-year-old daug hter. We would have been outraged." After pointing out that there are many, many $\mathrm{C}$ anadians suffering from "chronic pain of non-malignant origin," whose murder would not be widely viewed as a justifiable means of alleviating their pain, Dr. So merville concludes, "W e wouldn't kill her if she was a normal twelve-year-old girl, we wouldn't kill her if all she had [wrong with her] was pain, but we think it's O.K. to kill her — some people do - why? [It has to be] becau se she's disabled." 14
If Dr. Somerville is correct in her analysis, as I believe she is, there are some very serious implications for people living with severe disabilities in this country. The mass media's coverage of the Latimer case has clearly and consistently portrayed Tracy Latimer as an Other, whose severe disability made her life only a painful existence, a burden to herse lf and her family. When this portrayal of Tracy is contrasted with the typical depiction of Robert Latimer as a devoted parent and a well-liked, well-respected member of the community, it becomes painfully evident that the mass media is at once mirroring and perpetuating the common public perception of people with severe disabilities as somehow less-than-human beings condemned to a burdensome, pain-filled existence. The lives of people with severe disabilities are thus being subtly but systematically devalued by our society. This is an issue that should be of great concern, not just to people living with severe disabilities, but to everyone who values equality and justice in this country.

\section{Heidi L. Janz}

Doctoral Candidate, Department of English, University of Alberta. 